\title{
THE IMPACT OF DEMOGRAPHY ON PSYCHOLOGICAL CAPITAL: AN EMPIRICAL STUDY IN THE RETAIL SECTOR
}

\author{
Ms. Puja Prasad \\ Research scholar, GITAM Institute of Management, GITAM Deemed to be University \\ Visakhapatnam, AP, India \\ Dr. K V Sandhyavani \\ Assistant Professor, GITAM Institute of Management, GITAM Deemed to be University, \\ Visakhapatnam, AP, India
}

\begin{abstract}
In the current context of the Organization, which is characterized by high competition, a stimulating and constantly evolving environment, all organizations now focus more on developing and maintaining human capital rather than focusing more on financial capital and physics capital. Psychological capital is a central concept of positive psychology consisting of psychological resources of Self-Efficacy, Hope, Optimism and Resilience. Psychological capital leads to developing the positive behavior and attitude of an individual in the organization. The main objective of the study was to examine which factor of psychological capital influences employees in the retail sector and, secondly, study the correlation between the demographic profile of the respondents and the psychological capital. Around 100 employees were selected in the retail sector and a random sample was used to select the sample size of the population. SPSS 23.00 was used to analyze the data. The result of the study reveals that there is positive significant relationships between work experience, age group, education on psychological capital and designation have no significant relationship with psychological capital.
\end{abstract}

Key word: Psychological Capital, Hope, Optimism, Self-Efficacy, and Resilience.

Cite this Article: Ms. Puja Prasad and Dr. K V Sandhyavani, the Impact of Demography on Psychological Capital: an Empirical Study in the Retail Sector, International Journal of Management, 10 (1), 2019, pp. 43-50.

http://iaeme.com/Home/issue/IJM?Volume=10\&Issue $=1$

\section{INTRODUCTION}

Positivity in the workplace has been recognized in the field of managerial behavior since its inception and is present in the works of its founding fathers, such as Douglas McGregor and Abraham Maslow. However, present economic conditions and the rapidly changing environment facing today's organizations require an even greater emphasis on a positive tactic 
to manage and develop the human resources. The context in which positive research is conducted refers to a highly competitive business environment characterized by globalization and technological advances; Change the expectations of employers and employees. PsyCap is presented here as an emerging top-level model in which organizations can invest and develop in their workforce to achieve real and sustained growth and performance. PsyCap can help provide and contribute to the call for a new perspective and an approach to managing competitive advantage in the "flat world" environment. However, PsyCap cannot work in a vacuum and that is why we hope that a favorable organizational climate can play an important role. Psychological capital, as a central multidimensional construct made up of hope, optimism, effectiveness, and resilience is strongly correlated with employee performance and other attitudes and behaviors related to work. Going beyond human capital, that is "what you know" and social capital, that is "who you know", psychological capital, worried about "who you are" and "what you can become", is also identified as a source of competitive advantage based on context specific resources, renewable and difficult to imitate. Employees with high levels of PsyCap have more positive individual attitudes, such as greater job satisfaction and less intention to leave the current job. In addition, these employees showed greater well-being, as well as more individual and team-like behaviors, such as extra-role behaviors, less counterproductive work behavior and absenteeism. Furthermore, several studies have consistently reported a positive connection between PsyCap and performance in different dimensions (for example, individual work performance, financial performance and manager qualification). Finally, Psy Cap at the organizational level is strongly related to the subsequent financial performance of the organization.

\section{REVIEW LITERATURE}

Mohsen Golparvar (2014) purpose of the paper was who study the role of organizations ethical climate (caring, laws, rules, services, and independence) on psychological capital components. To analyze the data Pearson correlation efficient and multiple regression was done in selecting 267 railway employees from Isfahan, Iran. The outcome demonstrates that there is a significant relationship among self-efficacy, resilience, hope, and optimism which some of the ethical climate of the organization. The regression analysis predicts that caring and resilience is predicted by services, service, and independence predict hope and self-efficacy.

Ronald A. Levene et.al (2015) Purpose who address the rapid growth of technological capital research and explain psychological capital as a positive situation where the development of the individual can be done through self-resilience, optimism, hope, self-efficacy, and resilience. It was revealed that positive psychological capital help in reducing cost and mitigate influence in an organization.

Xiaowei Qiu, (2015) aim to the study was to examine the effect of psychological capital on the innovation performance of psychological capital on the innovation performance of the technical professional employees. To analyze the data hierarchical regression method was used selecting 347 respondents. The study demonstrates that there is a significant relationship between performance innovation and psychological capital and knowledge sharing please a mediating role between two variables. To enhance performance of employee a company should emphasize on the psychological capital and built a learning organization.-efficacy.

Sanda Grudić Kvasić et.al ( 2016) demonstrate the empirical and meta-analytical evidence supporting the theoretical proposals that at Higher order factor consisting of optimism, efficacy, hope, and the resilience has strong implications for the work-related attitudes and behavior as well as performance.

Jose M. Leon-Perez et.al (2016) in the research paper the main effects of psychological capital on burn out individual and moderate cross intragroup conflict, conflict management 
climate and burn out. Using cross-sectional survey 798 workers were selected from 55 units. It was revealed that there is an effect of psychological capital on quality of service and burn out. Whereas there is a negative effect between conflict management, Infra group conflict and quality of services.

Youssef-Morgan et.al. (2017) paper provides a background and precise meaning of the psychological capital and review its measures, antecedents, outcomes, need and significance of the research. it mainly focuses on the implication of psychological capital in the practical implication for the development of pathological capital, and positive leadership.

Qishan Chen et.al (2017) purpose of the study was to examine the relationship between leader and psychological capital of followers and its effect on the identification of organizational in the Chinese community. The respondents were 423 followers on 34 work teams, each with its respective team leader. To analyze the association among participants demographic background, human capital, and tenure was studied. It was revealed that at leader psychological capital positively impact on the technological capital of followers through the mediating role of organizational follower's identification.

\section{OBJECTIVES}

1. To study the demographic profile of the Retail Sector.

2. To study the relationship between select demographic variables and Psychological Capital.

\subsection{Hypothesis}

1. There is no significant difference between the Psychological capital and age group in retail sector.

2. There is no significant difference between the Psychological capital and education in retail sector.

3. There is no significant difference between the Psychological capital and experience retail sector.

4. There is no significant difference between the Psychological capital and designation retail sector.

\section{RESEARCH DESIGN AND DATA ANALYSIS}

The study use both primary and secondary data and primary data was collected through a Psychological Capital Questionnaire (24 items) Fred Luthans, Bruce J. Avolio, \& James B. Avey. The secondary data are collected through journal, articles and books. The questionnaire was distributed to 115 employees from the retail sector.After eliminating the incomplete responses, 100 samples were obtained. Section 1 consists of questions related to Demographic variable, and second section consists of question related to psychological capital. The respondents are asked to give their opinion on a likert scale of 1 to 7 indicating strongly disagree to strongly agree. The SPSS 23.00 version was used for the data analysis. The reliability test was done and the cronbach's alpha values (greater than 0.7 ) indicated that instrument used for the data collection is highly reliable. 
Table 1: Reliability Analysis

\begin{tabular}{|c|c|}
\hline Scale & Cronbach's Alpha \\
\hline Overall & .885 \\
\hline Hope & .850 \\
\hline Optimism & .850 \\
\hline Self-Efficacy & .872 \\
\hline Resilience & .857 \\
\hline
\end{tabular}

Table 2: Illustration of Demographics

\begin{tabular}{|c|c|c|c|}
\hline \multicolumn{2}{|c|}{ Demographic profile $(\mathrm{N}=100)$} & Number & Percentage \\
\hline \multirow{2}{*}{ Gender } & Female & 35 & 35.0 \\
\hline & Male & 65 & 65.0 \\
\hline \multirow{3}{*}{ Age } & Under 20 & 5 & 5.0 \\
\hline & $20-29$ & 88 & 88.0 \\
\hline & $30-39$ & 7 & 7.0 \\
\hline \multirow{2}{*}{ Marital Status } & Married & 10 & 10.0 \\
\hline & Unmarried & 90 & 90.0 \\
\hline \multirow{3}{*}{ Education } & Intermediate & 33 & 33.0 \\
\hline & Graduate & 66 & 66.0 \\
\hline & Master degree & 1 & 1.0 \\
\hline \multirow{6}{*}{ Designation } & Team Member & 15 & 15.0 \\
\hline & Coordinator & 39 & 39.0 \\
\hline & Sales Man & 24 & 24.0 \\
\hline & Sales Women & 13 & 13.0 \\
\hline & CSDC & 4 & 4.0 \\
\hline & Cashier & 5 & 5.0 \\
\hline \multirow{6}{*}{ Experience } & 1 years & 3 & 3.0 \\
\hline & 2 years & 9 & 9.0 \\
\hline & 3 years & 35 & 35.0 \\
\hline & 4 years & 28 & 28.0 \\
\hline & 5 years & 18 & 18.0 \\
\hline & 6 years & 7 & 7.0 \\
\hline
\end{tabular}

The demographic profile of the respondents is shown in the table 2. From the study of 100 employees from the retail sector it was found that majority of the respondents are male which is 65 percent and women are only 35 percent. The majority of employees were in the age group of 20-29 total 88 percent of sample. Most of the respondents were unmarried and concerning educational qualification 66 percent were graduate and 33 percent .designation of the respondents were team member, coordinator ,sales man ,sales women, Customer service desk (CSDC), and cashier. The majority respondents having 3 year experience 35 percent, 4 year experience are 28 percent. 


\begin{tabular}{|c|c|c|c|c|c|}
\hline \multicolumn{6}{|c|}{ Table 3 Descriptive Statistics } \\
\hline & $\mathrm{N}$ & Minimum & Maximum & Mean & $\begin{array}{c}\text { Std. } \\
\text { Deviation }\end{array}$ \\
\hline Responsibility & 100 & 1 & 5 & 3.53 & 1.077 \\
\hline Task Assigned & 100 & 1 & 5 & 3.44 & 1.076 \\
\hline Work goal & 100 & 1 & 5 & 3.52 & 1.039 \\
\hline Creative work & 100 & 1 & 5 & 3.39 & 1.127 \\
\hline Feedback & 100 & 1 & 5 & 3.68 & 1.024 \\
\hline Role higher & 100 & 1 & 5 & 3.49 & 1.030 \\
\hline Bigger challenge & 100 & 0 & 5 & 3.49 & 1.096 \\
\hline $\begin{array}{c}\text { Skill } \\
\text { Development }\end{array}$ & 100 & 1 & 5 & 3.44 & 1.048 \\
\hline $\begin{array}{l}\text { Forward } \\
\text { Autonomy }\end{array}$ & 100 & 1 & 5 & 3.71 & 1.018 \\
\hline Regular feedback & 100 & 1 & 5 & 3.70 & .969 \\
\hline Job role & 100 & 1 & 5 & 3.42 & 1.075 \\
\hline Handle task & 100 & 1 & 5 & 3.68 & .963 \\
\hline Efforts & 100 & 1 & 5 & 3.63 & .991 \\
\hline Solve problem & 100 & 0 & 5 & 3.55 & 1.192 \\
\hline Ability learn & 100 & 1 & 5 & 3.52 & 1.049 \\
\hline Do things & 100 & 1 & 5 & 3.52 & 1.078 \\
\hline Unexpected & 100 & 0 & 5 & 3.51 & .990 \\
\hline $\begin{array}{c}\text { Facing } \\
\text { Difficulties }\end{array}$ & 100 & 1 & 5 & 3.52 & 1.159 \\
\hline Idea Innovative & 100 & 1 & 5 & 3.25 & 1.029 \\
\hline $\begin{array}{l}\text { Negative } \\
\text { Feedback }\end{array}$ & 100 & 1 & 5 & 3.32 & .984 \\
\hline $\begin{array}{l}\text { Valid N (List } \\
\text { wise) }\end{array}$ & 100 & & & & \\
\hline
\end{tabular}

Illustration -The mean and standard deviation of the response obtain from the retail sector employee, for each statement in the questionnaire is tabulated as shown above. Of all the statement presented in the statement "forward autonomy " had highest rank with a mean value score of 3.71 implying that employee in the retail is getting autonomy to work in work place the statement regular feedback was rank second rank with a mean score 3.70 which implies that regular feedback is given by the superior in their performance. Handle task and feedback had similar mean score 3.68 which means that employee handle task properly in their working hour and give feedback. 
Table 4: Exploratory factor analysis findings and Cronbach's alpha values

\begin{tabular}{|c|c|c|}
\hline Sl.no & Psychological capital scale $(\alpha=0.885)$ & Standard factor load \\
\hline 1 & Optimism & $\alpha=.850$ \\
\hline & Responsibility & .820 \\
\hline & Task Assigned & .812 \\
\hline & Work goal & .684 \\
\hline & Creative work & .617 \\
\hline 2 & Feedback & $\alpha=.850$ \\
\hline & Hope & .712 \\
\hline & Role higher & .716 \\
\hline & Bigger challenge & .846 \\
\hline & Skill Development & .676 \\
\hline & Forward Autonomy & .645 \\
\hline 3 & Regular feedback & .872 \\
\hline & Self-Efficacy & .796 \\
\hline & Job role & .679 \\
\hline & Handle task & .593 \\
\hline & Efforts & .789 \\
\hline & Solve problem & $\alpha=.857$ \\
\hline & Ability learn & .764 \\
\hline & Resilience & .818 \\
\hline & Do things & .531 \\
\hline & Unexpected & .793 \\
\hline & Facing Difficulties & Idea Innovative \\
\hline
\end{tabular}

In addition, for reliability tests of scales, Cronbach's alpha coefficients were calculated and shown opposite the dimensions in Table 4. Accordingly, self-sufficiency dimension consisting of 5 expressions in psychological capital scale has 0.872 Cronbach's alpha value; hope dimension consisting of 5 expressions has 0.850 Cronbach's alpha value; resilience dimension consisting of 5 expressions has .857 Cronbach's alpha value; optimism dimension consisting of 5 expressions has .850 Cronbach's alpha value. When psychological capital scale was entirely subject to reliability analysis, the Cronbach's alpha value of the scale with 20 questions was found as 0.885 .

KMO and Bartlett's Test

\begin{tabular}{|c|c|}
\hline $\begin{array}{c}\text { Kaiser-Meyer-Olkin Measure of Sampling } \\
\text { Adequacy }\end{array}$ & .864 \\
\hline Bartlett's Test of Sphericity Approx. Chi-Square & 1383.166 \\
\hline df & 190 \\
\hline Sig. & .000 \\
\hline
\end{tabular}


Table 5 ANOVA

\begin{tabular}{|c|c|c|c|c|c|c|}
\hline $\begin{array}{c}\text { Work } \\
\text { Experience }\end{array}$ & $\begin{array}{l}\text { Between } \\
\text { Groups }\end{array}$ & $\begin{array}{l}\text { Sum of } \\
\text { Squares }\end{array}$ & $\mathrm{df}$ & $\begin{array}{l}\text { Mean } \\
\text { Square }\end{array}$ & $\mathrm{F}$ & Sig. \\
\hline & $\begin{array}{l}\text { Within } \\
\text { Groups }\end{array}$ & 21.637 & 26 & .832 & 0.235 & .063 \\
\hline & Total & 29.658 & 44 & .674 & & \\
\hline \multirow[t]{3}{*}{ Designation } & $\begin{array}{l}\text { Between } \\
\text { Groups }\end{array}$ & 51.296 & 70 & & & \\
\hline & $\begin{array}{r}\text { Within } \\
\text { Groups }\end{array}$ & 140.041 & 26 & 5.386 & .836 & .682 \\
\hline & Total & 283.508 & 44 & 6.443 & & \\
\hline \multirow[t]{3}{*}{ Age Group } & $\begin{array}{l}\text { Between } \\
\text { Groups }\end{array}$ & 423.549 & 70 & & & \\
\hline & $\begin{array}{l}\text { Within } \\
\text { Groups }\end{array}$ & 4.561 & 26 & .175 & 1.744 & .051 \\
\hline & Total & 4.425 & 44 & .101 & & \\
\hline \multirow[t]{4}{*}{ Education } & $\begin{array}{l}\text { Between } \\
\text { Groups }\end{array}$ & 8.986 & 70 & & & \\
\hline & $\begin{array}{l}\text { Within } \\
\text { Groups }\end{array}$ & 8.171 & 26 & .314 & 0.423 & .048 \\
\hline & Total & 9.717 & 44 & .221 & & \\
\hline & & 17.887 & 70 & & & \\
\hline
\end{tabular}

Interpretation - The one way ANOVA on Psychological capital it was found that work experience, age group, education have high influence in the psychological capital expect designation has no influence in the Psychological Capital of employee working in retail sector.

\section{CONCLUSION}

The outcomes from this study showed that psychological capital of the Retail employee is influence by the age group, education and experience but there is no significant influence by designation of the employees. The PsyCap is still emerging, human resource managers in general, and especially those concerned with HRD, can be confident that at least at this stage of the research, PsyCap has a strong and significant relationship with established desirable outcomes. The Recommendation would be for Retail organizations to proactively develop and manage the self-efficacy, hope, optimism, and resilience of their nursing workforce in order to achieve outstanding.

\section{REFERENCE}

[1] Luthans, F., Youssef, C. M., \& Avolio, B. J, Psychological capital: Developing the human competitive edge. Oxford, UK: Oxford University Press, 2007.

[2] Avey, J. B., Luthans, F., \& Youssef, C. M, The additive value of positive psychological capital in predicting work attitudes and behaviors. Journal of Management, 36(2), 2010.pp 430-452.

[3] Dr.R.Sathya, Consumers Intention Of Buying Private Label Brands In Food And Grocery Retail Sector In Chennai, International Journal of Management (IJM), Volume 6, Issue 2, February (2015), pp. 74-82

[4] Avey, J. B., Luthans, F., \& Jensen, S. M. Psychological capital: A positive resource for combating employee stress and turnover. Human Resource Management, 48, 2009, pp 677693. 
[5] Gökçen, M. Psychological Capital: Definition, Components and Effects. British Journal of Education, Society \& Behavioral Science, 5(3), 2015, pp 244-25.

[6] Jose M. Leon-Perez, M. A.-R., the Role of Psychological Capital and Intragroup Conflict on Employees' Burnout and Quality of Service: A Multilevel Approach, Frontiers in Psychology, 7, 2016, pp $1-11$

[7] Dr. C. Swarnalatha and T.S. Prasanna, Employee Engagement From A Retail Sector Perspective, International Journal of Marketing and Human Resource Management (IJMHRM), Volume 4, Issue 1, January - April 2013

[8] KVASIĆ, Z. C, Managing employees' psychological capital, An Enterprise Odyssey: Saving the Sinking Ship through Human Capital". 2016.

[9] Levene, R. A, Positive Psychology at Work: Psychological Capital and Thriving as Pathways to Employee. Master of Applied Positive Psychology (MAPP) Capstone Projects, 88, 2015.

[10] Luthans, C. M.-M, Psychological Capital and Well-being. Conceptual Review, 2014.

[11] Mohsen Golparvar and Afsaneh Rahmati Azarmonabadi, Explaining Psychological Capital Components through Organization's Ethical Climate Components. International Journal of Business, Economics and Management, 1(8), 2014. 216-228.

[12] Qishan Chen, Z. W.-T. Influence of Leaders' Psychological Capital on Their Followers: Multilevel Mediation Effect of Organizational Identification. Front Psychol. 2017; 8: 1776

[13] Xiaowei Qiu, X. Y. The Effect of Psychological Capital and Knowledge Sharing on Innovation Performance for Professional Technical. Journal of Service Science and Management, 8, 2015, pp 545-551.

[14] Dr. R. Prabusankar, V. Praveenkumar and Rajkumar. N, A Study on Influence of Supply Chain Management Practices on Product Quality and Performance of Organized Retail Sector in Tamil Nadu, International Journal of Mechanical Engineering and Technology, 9(7), 2018, pp. 46-54.

[15] Youssef-Morgan, F. L. Psychological Capital: An Evidence-Based Positive Approach. Annual Review of Organizational Psychology and Organizational Behavior, 4, 2017, pp 339366.

[16] Garg, P., Rastogi, R, Effect of psychological wellbeing on organization commitment of employees. The IUP Journal of Organizational Behavior, Vol 8, No 2, 2009, pp 42-51.

[17] Gohel, K., Psychological Capital as a Determinant of Employee Satisfaction. International Referred Research Journal, 3(36), 2012, pp 34-37. 